\title{
Unified Design Methodology for State Information Systems
}

\author{
Anton Makarov ${ }^{1,2}$ and Andrey Shabunin ${ }^{1}$ \\ ${ }^{1}$ St. Petersburg State University, 7/9, Universitetskaya nab., St. Petersburg, 199034, Russia \\ ${ }^{2}$ Saint Petersburg Electrotechnical University "LETI", 5, Professora Popova ul., St. Petersburg, 197376, Russia
}

\begin{abstract}
The development of state information systems, state electronic services, and electronic government systems require special approaches. However, at present, the requirements for the design notation of domestic state software are not defined and fixed. In the established practice, in the development of state software projects with a certain specificity and increased social significance, already existing technological solutions used in the private business are applied to the state information systems for various state departments of the Russian Federation. For the design of the state information systems and state e-services, it is suggested to use the unified methodology proposed by the authors, which includes subjects and objects, actions and processes, administrative restrictions, the IDEF0 standard, workflow class notation, the UML standard. The use of the proposed unified design methodology significantly structures, unifies and simplifies state software development. The advantages of using the proposed approach are illustrated in the implemented project to create a domestic customs inspection system.
\end{abstract}

\section{Keywords}

Computer-aided design, electronic document management system, IDEF0, BPM, UML

\section{Introduction}

The Russian Federation took 36th place in the United Nations global ranking of electronic government (e-government) development in 2020 [1]. It is four lines lower than in 2018 and one line lower than in 2016. This ranking tracks progress in development of e-government systems and corresponding electronic services (e-services) through the biennial E-Government Development Index.

The Russian Federation position evolution in the United Nations E-Government ranking is shown in the Figure 1.

When developing state information systems and state e-services, it is clear that it is necessary to use special approaches (see, for example, [2-6]). This paper continues studies on the automation of electronic document management in various departments of state authorities, initiated in the works of authors on the design and software development of e-government systems in the Russian Federation.

For example, the main difficulty arising in the development of domestic customs inspection systems is the lack of domestic practice, which involves the construction of a continuous human-machine system and the automation of the interaction process. Note that strict restrictions are imposed on foreign technologies; in the best case, only the purchase of imported systems is possible together with further support. Therefore, the task is to create a domestic software and hardware inspection system, including the design methodology, development and implementation of the constructed inspection system. In fact, this leads to the solution of the problem of import substitution in the Customs Service.

\footnotetext{
Proceedings of MIP Computing-V 2022: V International Scientific Workshop on Modeling, Information Processing and Computing, January 25, 2022, Krasnoyarsk, Russia

EMAIL: a.a.makarov@spbu.ru (Anton Makarov); shandr52@gmail.com (Andrey Shabunin) ORCID: 0000-0001-9539-6105 (Anton Makarov); 0000-0001-6604-9710 (Andrey Shabunin) (c) (i) C 2022 Copyright for this paper by its authors.

Use permitted under Creative Commons License Attribution 4.0 International (CC BY 4.0).

CEUR Workshop Proceedings (CEUR-WS.org)
} 


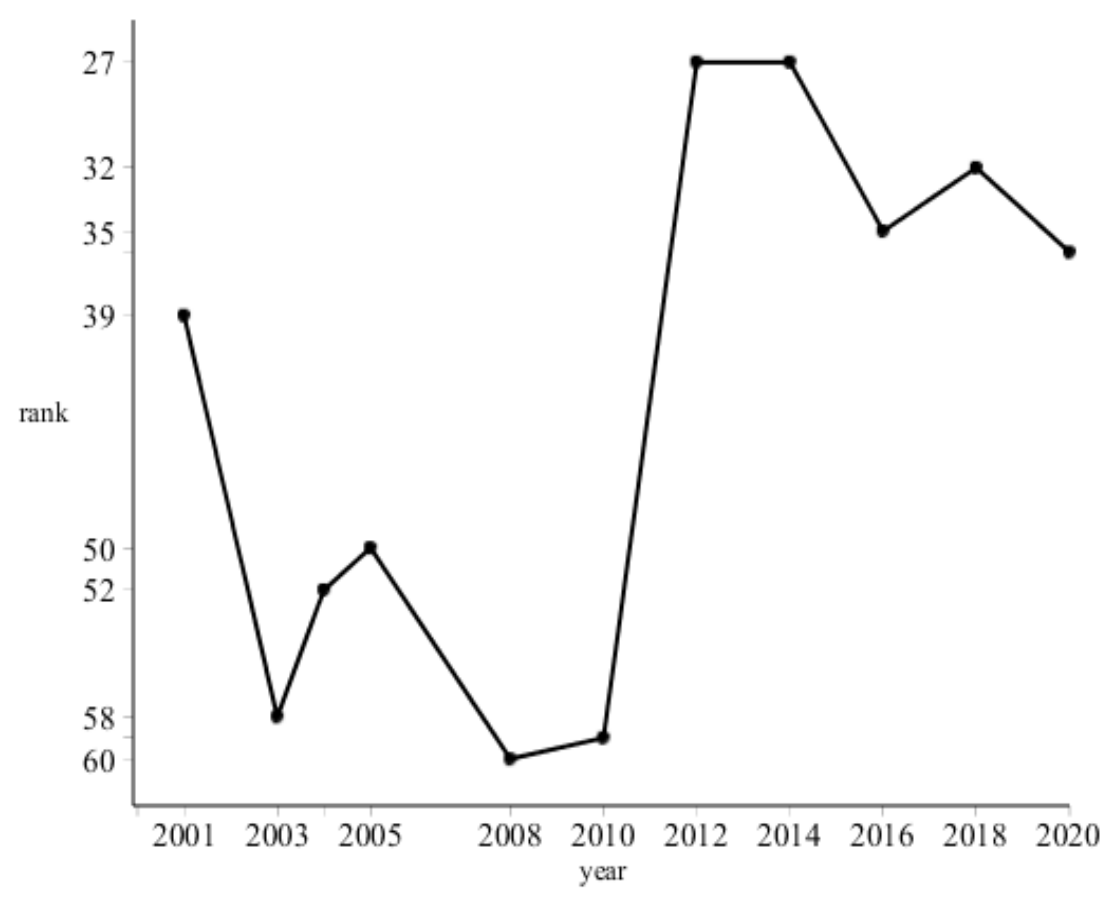

Figure 1: The Russian Federation position evolution in the United Nations E-Government ranking

\section{Software Design Methodologies Analysis}

Based on the analysis of software design methodologies (for example, see [4]), the following can be used as the basic methodology: UML, BPEL, ARIS, and others. However, there is no notation allowing documents to generate a description of administrative regulations in the established format.

We offer using a unified approach, combining IDEF0 and BPM methodologies, with additional notation elements. The use of existing symbols and rules (IDEF0 and BPMN) as a notation guarantees stability, improves understanding of the project by all parties (customer, contractor, etc.) and reduces the design time (because ready-made notations are used).

The toolkit available in the notations described above is not intended for a detailed description of the specifications of state processes and is not able to qualitatively and fully reflect all business processes of state e-services. Thus objects and subjects (see details in [2, 4]) were added to the proposed notation. Such notations as S-BPM, RDF, and some others also contain elements such as objects and subjects. They are successfully used in commercial projects, but they are not fully suitable for domestic state software projects.

An object is an entity that is affected. A subject is some influencing (acting) entity (for example, it can be both the applicant and the office). The description of new parameters contributes to the generation of detailed specifications, with the help of which it is possible to transfer the developed state software project to another state department, which meets the main principles of creating e-government projects. The process is called the interaction of subjects, their influence on objects through their actions.

Figure 2 shows the process of acceptance of documents for registration of a land plot with the additional administrative regulations element of notation. 


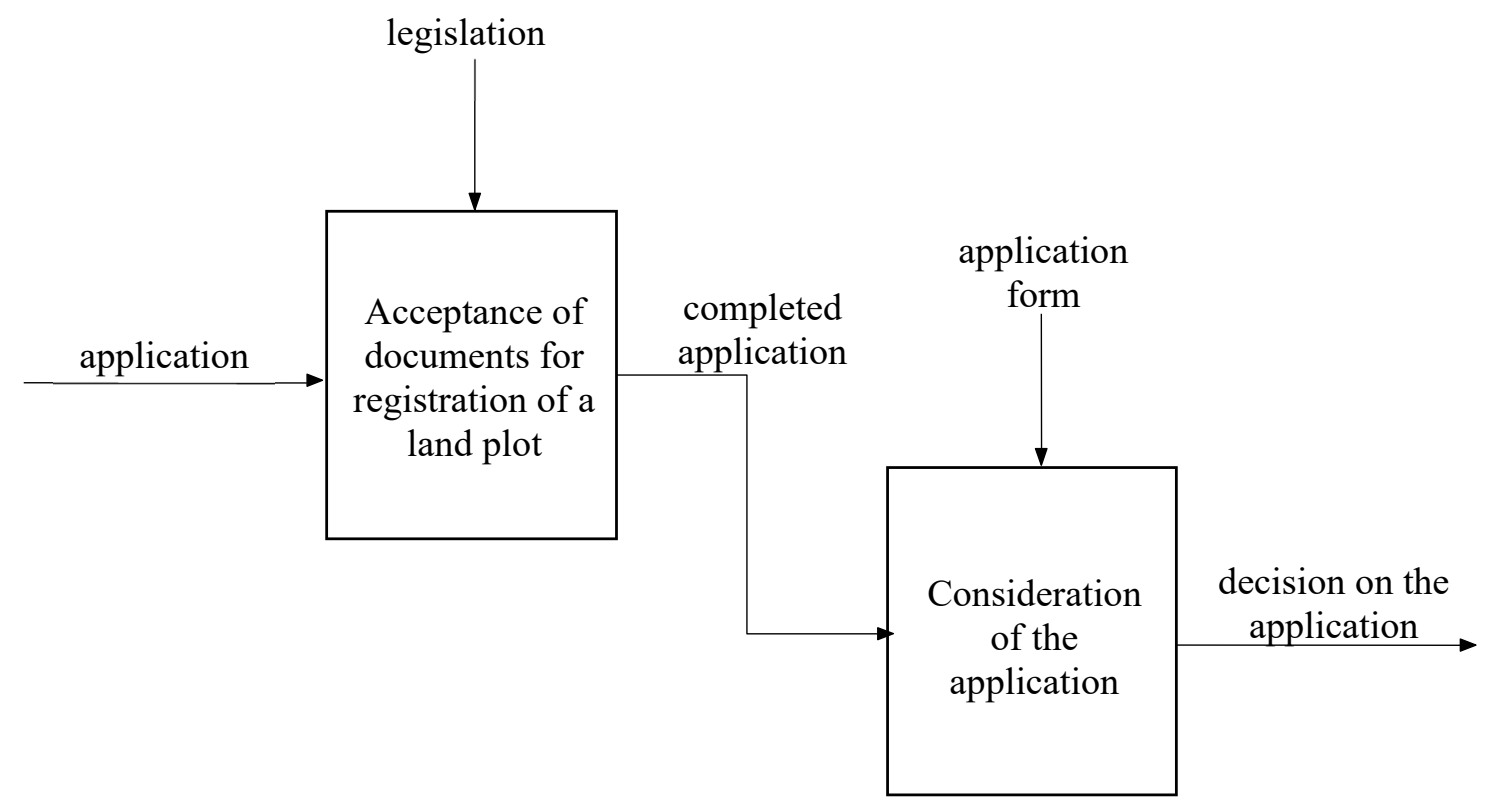

Figure 2: Diagram of acceptance of documents for registration of a land plot

\section{Single Unified Design Methodology}

An analysis of state information systems creation and e-services development show the feasibility of creating a certain combined design methodology that combines various approaches. We propose to use a single unified design methodology, which includes subjects and objects, actions and processes, administrative restrictions, the IDEF0 standard. This standard greatly simplifies the manager's understanding of the used business process model and contributes to the full implementation of the development strategy of the relevant department.

In the author's methodology also included workflow class notation for lower levels (the sequence of execution of operations for developers), the UML standard for a more detailed description of the system (especially the logic of behavior of its individual components).

Using the proposed unified design methodology significantly structures, unifies and simplifies state software development.

The following Table 1 gives a summary of comparison of different design methodologies.

\section{Table 1}

Comparison of approaches

\begin{tabular}{|c|c|c|c|c|c|c|}
\hline Approach & $\begin{array}{l}\text { Subjects/ } \\
\text { objects }\end{array}$ & $\begin{array}{l}\text { Processes/ } \\
\text { functions }\end{array}$ & $\begin{array}{l}\text { Understanding } \\
\text { of the process }\end{array}$ & Notation & $\begin{array}{l}\text { Control } \\
\text { flow in } \\
\text { business } \\
\text { processes } \\
\text { modeling }\end{array}$ & $\begin{array}{l}\text { Purpose of } \\
\text { approach }\end{array}$ \\
\hline BPM & $\begin{array}{c}\text { object } \\
\text { approach }\end{array}$ & $\begin{array}{l}\text { process } \\
\text { approach }\end{array}$ & $\begin{array}{l}\text { one complex } \\
\text { state machine }\end{array}$ & BPMN & yes & $\begin{array}{c}\text { Build, } \\
\text { reengineer, } \\
\text { integrate, } \\
\text { qualitatively } \\
\text { implement }\end{array}$ \\
\hline S-BPM & $\begin{array}{c}\text { subject } \\
\text { approach }\end{array}$ & $\begin{array}{l}\text { process- } \\
\text { functional } \\
\text { approach }\end{array}$ & $\begin{array}{l}\text { set of simple } \\
\text { state machines }\end{array}$ & S-BPM & no & $\begin{array}{c}\text { Automate as } \\
\text { quickly as } \\
\text { possible, } \\
\text { begin to }\end{array}$ \\
\hline
\end{tabular}




\begin{tabular}{|c|c|c|c|c|c|c|}
\hline & & & & & & $\begin{array}{c}\text { execute and } \\
\text { manage of } \\
\text { business } \\
\text { processes }\end{array}$ \\
\hline IDEFO & - & $\begin{array}{l}\text { functional } \\
\text { approach }\end{array}$ & $\begin{array}{l}\text { one complex } \\
\text { state machine }\end{array}$ & IDEFO & yes & $\begin{array}{c}\text { Create the } \\
\text { most } \\
\text { accurate } \\
\text { functional } \\
\text { model }\end{array}$ \\
\hline $\begin{array}{l}\text { Proposed } \\
\text { approach }\end{array}$ & $\begin{array}{c}\text { object- } \\
\text { subject } \\
\text { approach } \\
\text { (both are } \\
\text { used) }\end{array}$ & $\begin{array}{c}\text { functional- } \\
\text { process } \\
\text { approach }\end{array}$ & $\begin{array}{c}\text { set of simple } \\
\text { state machines }\end{array}$ & $\begin{array}{l}\text { IDEFO } \\
\text { BPMN }\end{array}$ & yes & $\begin{array}{c}\text { Create a } \\
\text { functional } \\
\text { model of } \\
\text { work, } \\
\text { automate, } \\
\text { integrate } \\
\text { and } \\
\text { implement }\end{array}$ \\
\hline
\end{tabular}

\section{Implications}

The benefits of using the proposed approach can be illustrated on the implemented project on the creation of the customs inspection system in the Volga Customs. In the notation used in the project, the functional model for conducting customs clearance of goods and the automatic generation of related documents are as follows, see Figure 3.

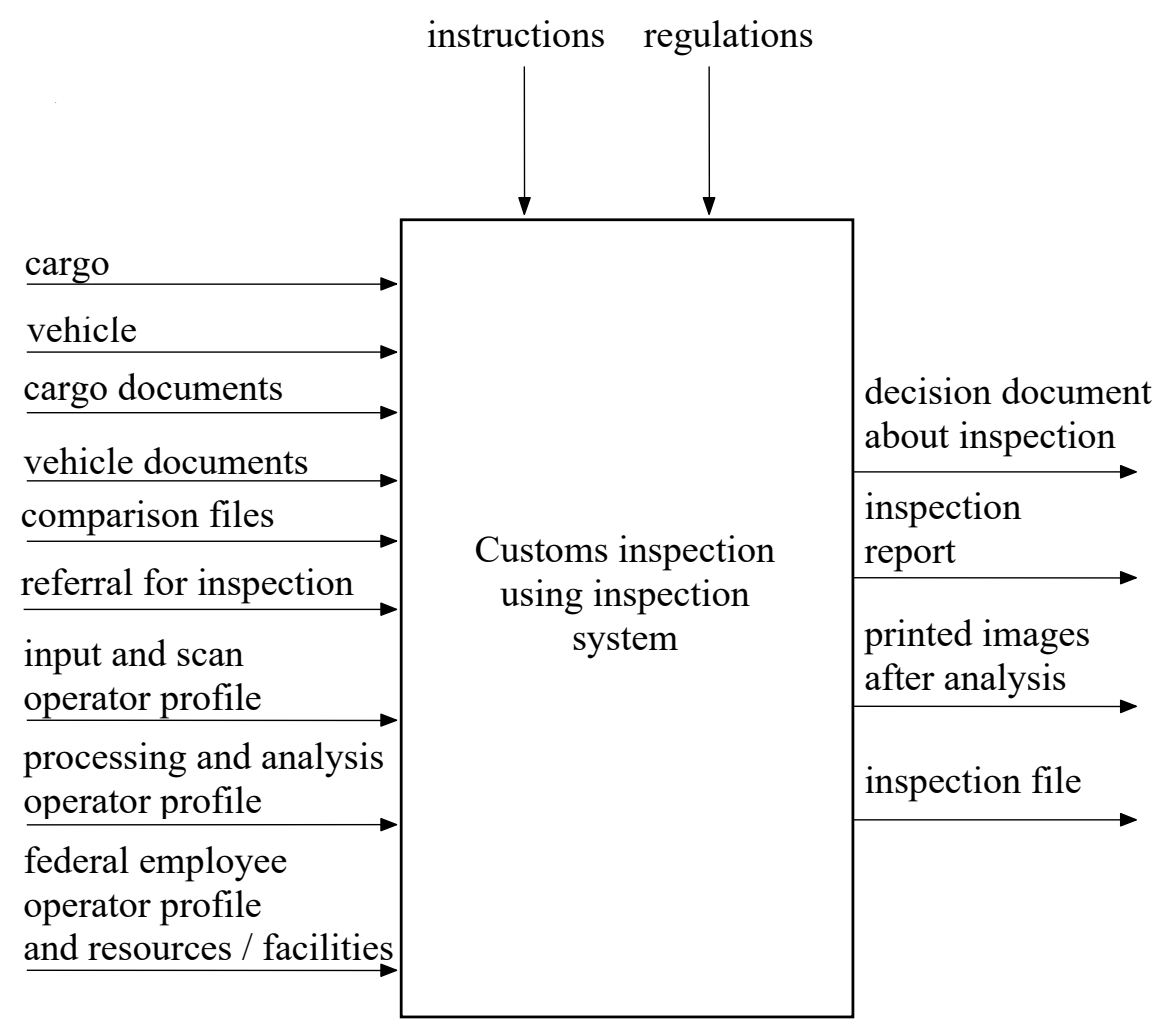

Figure 3: Diagram of the customs inspection 
A distinctive feature of the top-level diagram is the manager's traceable point of view on the entire business process and the final inspection result. The input parameters and the result of the customs inspection system work are clearly visible. Of course, the basic algorithm of the customs inspection system work requires a more detailed study. Therefore, it is described at the lower levels, but using the same notation, for example, see Figure 4.

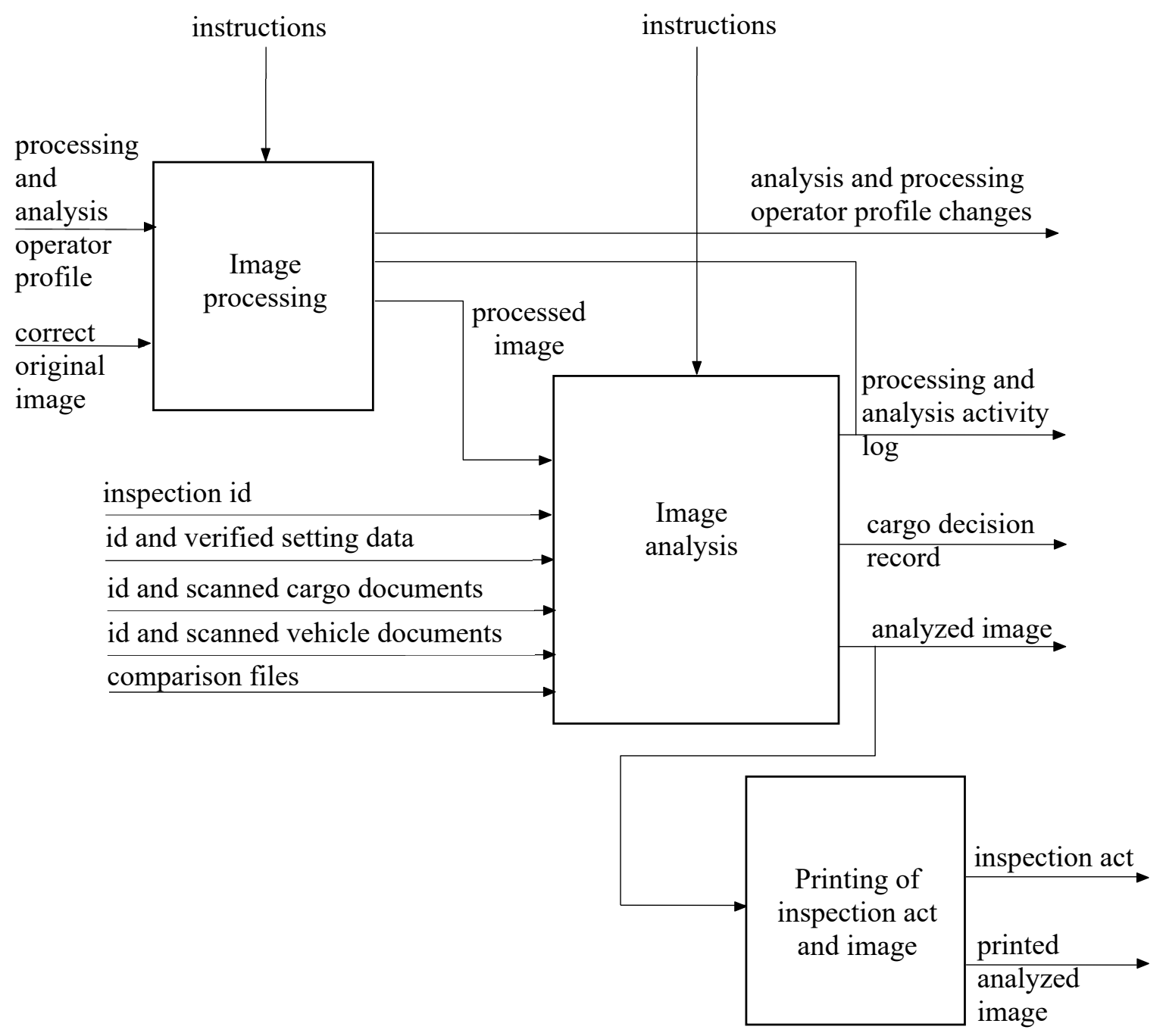

Figure 4: Diagram of the image processing and analysis

\section{Conclusion}

An analysis of state information systems creation and e-services development show the feasibility of creating a certain combined design methodology that combines various approaches. In the paper, it is proposed to use the single unified design methodology. The dissemination of the developed notation (see, for example, recent works $[7,8]$ ) accelerates the development of state e-services for e-government systems in the Russian Federation. Using the proposed unified design methodology significantly structures, unifies and simplifies state software development. The advantages of using the proposed approach are illustrated in the implemented project to create a domestic customs inspection system. 


\section{Acknowledgements}

The work was supported by the Ministry of Science and Higher Education of the Russian Federation (grant number No. FSEE-2021-0015).

\section{References}

[1] Digital Government in the Decade of Action for Sustainable Development. United Nations EGovernment Survey, 2020. URL: https://publicadministration.un.org/egovkb/en-us/Reports/UNE-Government-Survey-2020.

[2] A. A. Makarov, A. N. Shabunin, Features of the design of electronic services for public authorities, in: N. V. Smirnov, T. E. Smirnova (Eds.), Proceedings of the 44th conf. on Control processes and stability, St. Petersburg, St. Petersburg University Publ., 2013, pp. 438-443.

[3] A. N. Shabunin, Design and Instrumental Means of Electronic Services Generation for State Authorities, SPIIRAS Proceedings 7(30) (2013) 301-313. doi: 10.15622/sp.30.19.

[4] A. Makarov, A. Shabunin, On Design of Secure E-Services for Public Authority in the Russian Federation, in: Proceedings of the 20th Conference of Open Innovations Association (FRUCT), 2017, pp. 260-267. doi: 10.23919/FRUCT.2017.8071321.

[5] A. A. Makarov, A. N. Shabunin, On hardware-software inspection systems, in: Proceedings of the All-Russian Scientific Conference on Computer Sciences Problems "SPISOK-2019", 2019, pp. 136-140.

[6] O. G. Filatova, A. V. Chugunov, Electronic Participation: Conceptualization and Implementation Practice in Russia, Aletheia Publishing House, 2020.

[7] N. S. Mikhailov, A. S. Mikhailova, V. V. Kasatkin, Approach to construction of common information space of manufacturing enterprise, in Proceedings of the 2020 IEEE International Conference on Quality Management, Transport and Information Security, Information Technologies, 2020, pp. 385-390. doi: 10.1109/ITQMIS51053.2020.9322972.

[8] N. A. Panayiotou, V. P. Stavrou, Government to business e-services - A systematic literature review, Government Information Quarterly 38(2) (2021) 101576. doi: 10.1016/j.giq.2021.101576. 